Научная статья

УДК 882[092]

DOI 10.18101/2686-7095-2021-4-28-38

\title{
РЕЦЕПЦИЯ Ф. М. ДОСТОЕВСКОГО \\ В ТВОРЧЕСТВЕ А. И. КУПРИНА
}

\author{
(c) Ташлыков Сергей Андриянович \\ кандидат филологических наук, доцент, \\ Иркутский государственный университет \\ Россия, 664003, г. Иркутск, ул. Карла Маркса, 1 \\ taschlykoff@mail.ru
}

\begin{abstract}
Аннотация. В статье исследуется рецепция Ф. М. Достоевского в беллетристике и публицистике А. И. Куприна. В первой части статьи содержится анализ таких типов рецепции, как коммуникативный диалог, интерпретация, аллюзия. Коммуникативный диалог обнаруживается на персонажном (образ мечтателя) и мотивном (мотив безумия) уровнях. Выявляется сходство и отличие в реализации этих образов и мотивов в прозе Достоевского и Куприна. Еще один аспект рецепции - интерпретация отдельных жанровых структур (рождественский рассказ), а также сюжетов и образов. Обращение к образной системе романов Ф. М. Достоевского «Братья Карамазовы» и «Бесы», а также к их идеологической составляющей представлено в публицистике А. И. Куприна. Этот материал осмысляется во второй части статьи, которая демонстрирует, что в публицистике эмигрантского периода Куприн выступает комментатором, отчасти интегратором пророчеств того, кто «почуял идейные основы и характер грядущей революции русской, а может быть, и всемирной» (Н. А. Бердяев).

Ключевые слова: русская литература, Ф. М. Достоевский, А. И. Куприн, беллетристика, публицистика, рецепция, типы рецепции: коммуникативный диалог, интерпретация, аллюзия.
\end{abstract}

\section{Для цитирования}

Ташлькков С. А. Рецепция Ф. М. Достоевского в творчестве А. И. Куприна // Вестник Бурятского государственного университета. Филология. 2021. Вып. 4. С. 28-38.

\author{
... Куприн на протяжении всего своего \\ творчества неизменно оставался верным \\ учеником Л. Толстого, изменяя ему только по \\ отдельным поводам для Достоевского.
}

Димитрий Горбов

Влияние Ф. М. Достоевского на творчество А. И. Куприна - общее место в куприноведении. Еще рецензент «Русского богатства», оценивая первый сборник Куприна, писал: «Он особенно охотно изображает мрачные стороны жизни, животные страсти, измену, коварство, лицемерие... Изнанка жизни и человеческой души почти исключительно занимает г. Куприна в «Миниатюрах»... Думается, что г. Куприн и слишком здоров, и недостаточно силен, чтобы поднять эти исключительные болезненные чувства (здесь и далее выделено мной. - C. $T$.) до 
той высоты общего интереса, до которой мог их поднимать Достоевский» [2, c. 25,28$]$.

Как отечественные куприноведы (П. Н. Берков, Ф. И. Кулешов, А. А. Волков, Л. В. Крутикова и др.), так и их зарубежные коллеги (Luker N. Alexander Kuprin; Szymonik D. Poetyka prozy Alexandra Kuprina. 1889-1916; Алексиева Е. Реката на животата; Поетика на творчеството на Александър Куприн) также отмечали влияние Достоевского на творчество писателя.

Отмечая, что «рецепция наследия Достоевского ... явление яркое и разнообразное, стимулирующее творческую мысль писателей», С. Е. Трунин подчеркивает, что «наиболее распространенными типами рецепции у писателей-реалистов являются конкретизация, реконструкция, интерпретация, коммуникативный диалог» [21, с. 3].

Цель настоящей работы - выявить и осмыслить основные типы рецепции Достоевского в творчестве А. И. Куприна.

1. Обратимся вначале к художественной прозе А. И. Куприна.

Анализ его ранних новелл и ряда произведений зрелого периода («С улицы», «Поединок», «Гранатовый браслет» и др.) позволяет обнаружить три основных типа рецепции творчества Ф. И. Достоевского: коммуникативный диалог, интерпретация, аллюзия.

Коммуникативный диалог представлен на персонажном и мотивном уровне.

В системе персонажей обоих авторов чрезвычайно значимое место занимает образ мечтателя. У Достоевского он появляется в «Петербургской летописи» (1847): мечтатель - это «не человек, а какое-то странное существо среднего рода», «это кошмар петербургский, это олицетворенный грех, это трагедия, безмолвная, таинственная, угрюмая, дикая, со всеми неистовыми ужасами, со всеми катастрофами, перипетиями, завязками и развязками...» [5, т. 18, с. 32-33]. В повести «Белые ночи» (1848) Достоевский вновь обращается к этому образу.

У Куприна в газетной версии рассказа «Ясь» (1894) есть строки: «Уже не раз замечено, что есть между простым народом опасный тип замкнутого мечтателя. Думает, думает человек, никому своих мыслей не поверяя, да вдруг и удерет такое, что только руками разведешь. Или хватит по голове сестру родную, а сам будет с диким любопытством глядеть, как сочится кровь, либо деревню подожжет ни с того ни с сего. Какими темными загадочными путями протекает их мысль к этим удивительным результатам - бог весть» [16, т. 1, с. 491].

Как следует из приведенных цитат, мечтатели у обоих писателей - люди странные, опасные, непредсказуемые (ср. у Достоевского: трагедия, дикая, с ... неистовыми ужасами; у Куприна: вдруг удерет такое, хватит по голове, деревню подожжет ни с того ни с сего).

Однако типичные мечтатели Достоевского - интроверты, они углублены в себя», «смирны, незлобивы и боятся, чтобы их не затронули», «на улице ходят повесив голову, мало обращая внимания на окружающих, иногда и тут совершенно забывая действительность», «селятся они большею частию в глубоком уединении, по неприступным углам, как будто таясь в них от людей и от света...».

Мечтатель в ранней прозе Куприна скорее экстраверт. Он агрессивен, его поведение непредсказуемо, он действует «ни с того ни с сего». При этом зача- 
стую агрессия такого мечтателя направлена не на внешний мир, а на себя самого: разочаровавшись в своих мечтаниях и ожиданиях, он сводит счеты с жизнью. Таковы актриса театра Гольская («Последний дебют»), господский слуга Ясь («Славянская душа»), «маленький Мопассан» Сойманов («Странный случай»), студент-медик II курса Алексей Сумилов («Каприз») и др.

Все это свидетельствует о том, что интерпретация образа мечтателя у Достоевского и Куприна имеет как сходные, так и специфические черты.

Необходимо тем не менее еще раз подчеркнуть, что такой персонаж, который сосредоточен на своем внутреннем мире, на себе, на собственной духовной жизни, чрезвычайно важен для обоих писателей. Не случайно образ мечтателя не локализован в определенном творческом периоде - он является сквозным. Мечтателями заполнено «Великое Пятикнижие» Достоевского. «Мечтательство, являющееся характерной чертой русской души и объективно отразившее в себе драматический процесс протекания духовной жизни русского общества 1840 1870-хх гг., явилось одной из центральных тем творчества Достоевского в постижении тайн человеческого духа», — отмечает Э. М. Жилякова [6, с. 97].

Образ мечтателя занимает важное место и в зрелой прозе А. И. Куприна. Ярким примером является герой «Поединка» подпоручик Ромашов, в котором «осталось еще много ребяческого» и которого обуревают «мстительные, фантастические, опьяняющие мечты». Он представляет себя и блестящим, «изящным, снисходительно-небрежным, корректным и дерзко-вежливым» офицером генерального штаба, и военным шпионом в Германии, мужественно принимающим смерть, и ... Куприн подчеркивает привычку Ромашова «думать о самом себе картинно в третьем лице». Коммуникативный диалог как форма рецепции представлен не только на персонажном, но и на мотивном уровне.

Обоих писателей привлекает тема безумия, хотя А. И. Куприн, в отличие от Ф. И. Достоевского, сохранявшего интерес к этой теме на протяжении всего творческого пути $[18$, с. 33-38], постепенно отходит от нее и старается избегать «болезненной психологии», о которой писал Н. К. Михайловскому в конце октября - начале ноября 1896 г. [1, с. 196].

Мотив безумия представлен в первую очередь в ранней прозе Куприна («Психея», «Лунной ночью», «Славянская душа», «Безумие», «Мясо»).

Н. А. Даренская, исследуя поэтику рассказа Куприна «Лунной ночью» и осмысляя влияние «претекста-матрицы», коим является роман Ф. М. Достоевского «Преступление и наказание», на рассказ Куприна, подчеркивает: «Прежде всего писатель обыгрывает тему психического нездоровья или безумия, являющуюся опорным художественным концептом великого предшественника, а также состояния раздвоения - физического, психического, метафизического... Бесспорно, Куприна привлекал тип героя произведений Достоевского, находящегося в болезненном состоянии, состоянии психической раздвоенности. Раздвоение, раскол проявляется в расщеплении сознания героя рассказа “Лунной ночью"» [4, с. 49-52].

С мотивом безумия связан ранний очерк «Киевский Бедлам» (1895) [13, c. 386-394], посвященный проблеме душевнобольных. Этот очерк стоит в ряду других «медицинских» очерков Куприна, появившихся в «Киевлянине»: «В бактериологическом институте. І. Прививки против бешенства» (1900) и «Бактерио- 
логический институт. II. Антидифтеритная сыворотка» (1900) и, сближаясь с циклом производственных очерков [9, с. 431-437], характеризуется фактографичностью, документальностью и отсутствием художественного вымысла.

Особый аспект рецепции творчества Ф. И. Достоевского в творчестве А. И. Куприна связан с интерпретацией отдельных жанровых структур, а также сюжетов и образов.

Жанру рождественского рассказа отдали дань многие русские писатели. Как известно, традиционный календарный код предполагает наличие рождественского чуда, однако Ф. М. Достоевский в рассказе «Мальчик у Христа на елке» (1876) нарушает традицию: «А внизу наутро дворники нашли маленький трупик забежавшего и замерзшего за дровами мальчика; разыскали и его маму... Та умерла еще прежде его; оба свиделись у господа бога в небе» [5, т. 22, с. 17] (Заметим попутно, что в таком же ключе развивается сюжет в «Ангелочке» Л. Андреева, где так же ощутимо дыхание смерти: харкающий кровью отец Сашки, тающий над печкой восковой ангелочек...).

«Чудесный доктор» (1897) А. И. Куприна, являясь своеобразной интерпретацией рассказа «Мальчик у Христа на елке», скорее следует традиционному канону: здесь ощутимо дыхание жизни, присутствие рождественского чуда: наполняется теплом подземелье, где «уже более года жили Мерцаловы», насыщаются голодные, воскресает больной ребенок.

Перекличка мотивов, сюжетов и образов Куприна и Достоевского отмечена в работах ряда исследователей.

«В сущности, социально-фантастический рассказ “Королевский парк”, пишет Ф. И. Кулешов, - заключал вариацию мотивов творчества Достоевского, в частности его “Записок из подполья" и "Подростка", ядовито иронизировавшего над "хрустальными дворцами” будущего, в которых все будет устроено "чрезвычайно благоразумно", да зато жить там будет "ужасно скучно”, и люди, пожалуй, начнут втыкать в тело друг другу золотые булавки, ибо чего только человек не выдумает от скуки!» [10, с. 74].

«В образной системе произведений Куприна, - отмечает Т. А. Кайманова, проявляются персонажи, от которых веет аллюзией из мира Достоевского: в рассказе "Звезда Соломона" - образ будничного жалкого черта; в рассказе "Система" - образ игрока в рулетку. В рассказе "К славе" Лидочка своим душевным надрывом напоминает Настасью Филипповну — их обоих Куприн причислил к категории “скорбящих и озлобленных”...» [7, с. 155].

Этот перечень произведений Куприна может быть дополнен: отсылает к миру Достоевского рассказ «Черный туман» (1905) с подзаголовком «Петербургский случай»; исповедь «человека с улицы» («С улицы», 1904) восходит к исповеди Мармеладова («Преступление и наказание»).

Специфическая форма рецепции Достоевского в некоторых произведениях А. И. Куприна - это прямое введение в текст его имени, уже связанного с целым комплексом коннотаций, понятных образованному читателю.

Можно сказать, что герои Куприна поверяются именем Достоевского. Не выдерживает такой поверки «учитель гимназии по предмету русской грамматики и литературы» Костыка, «злорадно и властно» экзаменуя «одного за другим безмолвных исполинов»: Пушкина, Лермонтова, Гоголя, Тургенева и Достоевского, 
которого «одобрил за полячишек», но пожурил за «сектантское» православие: «Не то хлыстовщина, не то штунда» («Исполины», 1907).

Выдерживают поверку семинаристы, которые «читали вслух запрещенного начальством Достоевского и нашли в его романе “Братья Карамазовы” в лице Алеши странное и умилительное сходство со своим сотоварищем, добрым и всеми любимым Люминарским» («Алеша», 1916).

Отдельного внимания заслуживают еще два упоминания имени Достоевского. В лекции, прочитанной в Ессентуках 25 июля 1908 г., Куприн дает ироничную и выразительную оценку творчеству Ф. Сологуба: «Его роман "Мелкий бес" признан как крупное литературное явление. По моему мнению, это капля Достоевского на ведро воды. Это жизнь маленького, пошленького, гнусного человека, написанная с ужасающими подробностями, с мелочным и неправдоподобным ковырянием» [1, с. 302].

В статье «Вольная академия» (1916) Куприну «хочется думать» и верить, «что где-нибудь, в мерзлом окопе или в развалившейся халупе, сидит он (будущий Толстой или Достоевский. - C. T.), никому еще не ведомый, еще не чующий своего великого призвания, но уже бессознательно впивает своими широко открытыми глазами и умным послушным мозгом все слова, звуки, запахи, впечатления» $[16$, т. 9 , с. 149$]$.

2. Обратимся далее к публицистике А. И. Куприна, которая в целом ряде случаев содержательно, эмоционально, интенционально перекликается со знаменитыми «пророчествами» Ф. М. Достоевского.

Подводя итог 35-летней литературной деятельности А. И. Куприна, Саша Черный писал: «В день “юбилейный” - горький и безрадостный на чужбине день - одну новую сторону в литературно-эмигрантской деятельности А. И. Куприна хочется особенно выделить. Я говорю о его статьях», которые «связаны одной прямой линией: неугасимым неприятием и ненавистью к красному быту, красному политическому иезуитству и бесчеловечности». Творческий подвиг писателя Саша Черный сравнивает с подвижничеством его предшественников: «Величайшие мастера - Достоевский и Гейне - в свое время сменяли кисть художника на шпагу публициста, повинуясь чувству гражданского долга» $[19$, c. $380-381]$.

О. С. Фигурнова отмечала провидческий характер публицистики Куприна, «предсказавшей наступление и семидесятилетнее торжество коммунистического “земного рая" с его траурной символикой и культом мертвого тела в центре страны. Современники, близко знавшие писателя, отмечали в нем редкий дар бессознательного провидчества, ранее связывавшегося в русской литературе с именами Пушкина, Гоголя, Достоевского» [17, с. 17].

Сам Куприн упоминал о своей особенности «предугадывать будущее», он неоднократно говорил, что обладает неким пророческим даром. В одном из интервью Куприн сказал: «Предугадывать будущее я боюсь. До 18 февраля я считал себя обладателем очень тонкого чутья, и не один раз я предугадывал будущее. Мне почему-то казалось, что война должна окончиться 18 февраля, я твердо в это верил и говорил об этом на каждом шагу, но я жестоко ошибся... Больше уже предсказывать не берусь» $[22$, с. 5]. 
Однако после Октябрьского переворота Куприн изменяет своему слову, и в газете «Приневский край» прозвучало его зловещее пророчество: «Если же победят большевики, то голодными вы останетесь всегда - и ныне, и присно, и во веки веков...» («Еда», 1919) [17, с. 122].

Эмигрантская публицистика вообще наполнена различного рода предсказаниями Куприна, связанными с падением большевистского режима.

В газете «Русская жизнь» (1919. 24 нояб. № 221) было напечатано очередное пророчество: «Россия сумеет справиться с большевизмом еще и потому, что она... страна именно земледельческая, мужицкая, т. е. крестьянская и христианская. $<\ldots>$

Деревни никогда не забудут карательных отрядов, и о мужика-собственника неизменно расшибают лоб вожди научного социализма — и будут расшибать до самой смерти. $<\ldots>>$

Россия переболеет большевизмом гораздо скорее, чем это предполагается» $[12$, c. 33].

Художнику С. Животковскому Куприн в январе 1920 г. сказал: «Меня никогда не обманывало чувство предвидения. На этот раз я чувствую, что Петроград будет освобожден и все мы вздохнем с облегчением между февралем и июлем 1920 г.». Куприн даже просил Животковского записать эти слова, чтобы он позже мог проверить его предсказание [12, с. 17].

При этом в своем «чувстве предвидения» Куприн постоянно опирается на пророчества Достоевского, его роман «Бесы» [20].

И здесь следует сделать важное уточнение.

«Мысль о романе Ф. М. Достоевского “Бесы” (1871-1872) как о пророчестве русской революции, - пишет О. С. Фигурнова, - была выдвинута деятелями русского религиозно-философского возрождения начала ХХ в. (В. В. Розановым, Д. С. Мережковским, С. Н. Булгаковым, В. И. Ивановым, Н. А. Бердяевым) и в 1917-1918 гг. стала общепризнанной на страницах антибольшевистской печати, а затем и в литературе русского зарубежья» [17, с. 649-650].

Таким образом, особенностью публицистики Куприна является некоторая вторичность идеологического контента. Оригинальность заключается в его умении соотнести пророчества конца XIX в. с событиями века XX, очевидцем которых он был. Таким образом, здесь следует говорить о таком типе рецепции, как интерпретация.

Образ Достоевского, как уже отмечено, в основном связан с эмигрантской публицистикой, однако еще в 1917 г. Куприн обращается к роману «Бесы». В газете «Свободная Россия» (СР. 1917. № 12), появляется статья «В наши дни: Генерал Пфуль»: «Шигалев в "Бесах" страстно уверял, что достаточно в России отрубить только пятьдесят тысяч голов и наступит идиллическая эпоха. И делал при этом рукой такой короткий жест, как будто бы рубит голову. Бог избавил нас от практической шигалевщины» [13, с. 299].

На самом деле фразы, приписанной Куприным Шигалеву, в «Бесах» нет, но сама эта мысль присутствует. Она звучит из уст хромого преподавателя гимназии: «Нам вот предлагают, чрез разные подкидные листки иностранной фактуры сомкнуться и завести кучки с единственною целию всеобщего разрушения, под 
тем предлогом, что как мир ни лечи, все не вылечишь, а срезав радикально сто миллионов голов и тем облегчив себя, можно вернее перескочить через канавку».

Эту же мысль озвучивает Петр Верховенский: «“Сто миллионов голов”, это, может быть, еще и метафора, но чего их бояться, если при медленных бумажных мечтаниях деспотизм в какие-нибудь во сто лет съест не сто, а пятьсот миллионов голов?» [5, т. 10, с. 314-315].

Понятно, что этот образ «миллионов голов», которых бесьl готовы отдать за то, чтобы «перескочить через канавку», произвел такое впечатление на Куприна, что он - пусть неточно - цитирует его в собственном тексте, а потом еще раз обращается к образу Шигалева в статье «Законный срок» (Утренняя молва. 1918. 19 июня. № 4).

Писатель сравнивает В. И. Ленина с героем Достоевского: «Он же увеличенный в тысячу раз Шигалев из “Бесов", фанатик идей, идущий неуклонно и по-своему честно к ее крайним выводам, вплоть до абсурда». Вот один из абсурдных выводов Шигалева: «Выходя из безграничной свободы, я заключаю безграничным деспотизмом» (о Ленине как фанатике идей Куприн будет говорить в своей эмигрантской Лениниане [8, с. 305-310].

Образ Шигалева еще раз появится позднее, в публицистике эмигрантского периода. В статье «Тихий ужас» представлена «бесконечная цепь чудовищных фактов, из которых в прежнее время самый незначительный заставил бы нас закричать от боли, страха и отвращения». Перечисление всех этих «кошмар[ов] советской действительности, перед которыми бледнеют сумасшедший дом, каторга, тифозный бред и сама преисподняя», Куприн заканчивает словами: «Идет шигалевщина! Исполняются грозные слова Достоевского, сказанные им в “порыве великого гнева": Господи! Неужели и эта последняя кара не минует нашу грешную родину?» [13, с. 319].

Пророческое упоминание о шигалевщине не случайно: «У него (Шигалева. C. T.) каждый член общества смотрит один за другим и обязан доносом. Каждый принадлежит всем, а все каждому. Все рабы, и в рабстве равны. В крайних случаях клевета и убийство, а главное - равенство. Первым делом понижается уровень образования, наук и талантов. Высокий уровень наук и талантов доступен только высшим способностям, не надо высших способностей! Высшие способности всегда захватывали власть и были деспотами. Высшие способности не могут не быть деспотами и всегда развращали более, чем приносили пользы; их изгоняют или казнят. Цицерону отрезывается язык, Копернику выкалывают глаза, Шекспир побивается каменьями - вот шигалевщина! Рабы должны быть равны: без деспотизма еще не бывало ни свободы, ни равенства, но в стаде должно быть равенство, и вот шигалевщина!» [5, т. 10, с. 322].

В июне 1917 г. в газете «Свободная Россия» (СР. 1917. № 30) был напечатан очерк «Сердце народное (А. Ф. Керенский)», который Куприн завершает словами: «В Керенском же кипит наша кровь и бьется наше сердце». Очерк интересен тем, что в нем публицист обращается к роману «Братья Карамазовы». Защищая Керенского, он пишет: «Политические враги Керенского, ослепленные злобой, завистью и фанатической нетерпимостью, одурманенные подлым принципом цель оправдывает средства, - однажды дошли до того, что кинули в толпу зловещую и зловредную мысль: “А не метит ли Керенский в Наполеоны?” Поисти- 
не предположение достойно ублюдка Усть-Сысольской просвирни со Смердяковым» $[14$, с. 2].

В эмигрантской публицистике А. И. Куприна имя Достоевского становится своеобразной мерой оценки событий, происходящих в Советской России.

В 1920 г. в гельсингфорской газете «Новая русская жизнь» (далее - НРЖ) появляется статья А. И. Куприна «Пророчество первое» (НРЖ. 1920. 10 января. № 6. C. 2).

Системе точных цитат из романа «Бесы» предшествует авторское: «Страшная книга. Изумительная, беспощадная, пророческая книга. Апокалипсис ближайших дней, глумливый гневный, начертавший образами, жившими пятьдесят лет тому назад, всю суть нынешнего большевизма: его характеристику, лозунги, происхождение, идеологию, приемы, также его бессилие. Эту книгу “Бесы” Достоевского надо перечитать целиком. Она ужасна точна до портретности. Взятые мною из нее случайные выдержки я не осмеливаюсь даже сопровождать комментариями. Я только расположил их в некотором порядке». Куприн не комментирует Достоевского - цитаты говорят сами за себя.

«Что же это? - задается вопросом Куприн. - Достоевский был таким зловещим пророком, или большевики целиком воспользовались его гениальной буффонадой, чтобы превратить в свой катехизис?» $[15$, с. 2].

Статья Куприна «Пророчество второе» (НРЖ. 1920. 2 марта. № 50. С. 2) опять обращена к «Бесам»: «С месяц тому назад мы привели на столбцах нашей газеты, - напоминает читателям автор, - целый ряд выдержек из “Бесов" Достоевского. Несколько десятков строк великого "тайновидца духа" в сжатом и страшном виде обрисовывают идеологию и методы того современного русского большевизма, который Достоевский как будто бы провидел за сорок лет вперед» $[14$, c. 2].

В ряде статей 1920-х гг.: «Христоборцы» (НРЖ. 1920. 22 января. № 16. С. 2), «Нация» (НРЖ. 1920. 10 февраля. № 32), «Капитаны Тушины» (НРЖ. 1920. 4 марта. № 52), «Тихий ужас» (НРЖ. 1920. 22 мая. № 112; 23 мая. № 113; 26 мая. № 114; 27 мая. № 115), «Орочены» (Общее дело. 1921. 18 сентября. № 428), «Два юбилея» (Русская газета. 1924. 11 июля. № 67), «Мой герой — правда» (Русское время. 1926. 14 июля. № 327) — имя Достоевского появляется в разных контекстах и проявляется в разных ипостасях.

В статье «Христоборцы» Куприн обращается к типу русского атеиста, который, по словам Достоевского, «самое нелепое и готовое на всякое преступление существо» $[11$, с. 261] (ср. в «Бесах): «Атеист не может быть русским, атеист тотчас же перестает быть русским»).

В статье «Нация» упоминание о Достоевском становится своеобразным упреком, обращенным к русской нации: «Сказал ли кто-нибудь о Пушкине публично настоящее, большое, любовное национальное слово, за исключением Достоевского, которому и тогда, да, пожалуй, и теперь, совсем недавно, ставили в упрек его страстную, огненную любовь к России как к нации и к Пушкину как к ее величайшему выразителю?» [17, с. 150]. К этой теме Куприн обращается также в статье «Два юбилея».

В статье «Орочены» (1921) имя Достоевского наряду с именем Толстого открывает ряд имен, которые являют собой персонификацию русскости и которы- 
ми стоит гордиться: «Но мы вовсе не ботокуны, не орочены и не эскимосы! У нас Толстой и Достоевский. У нас Белелюбский строил мосты, Воронихин соборы, Щукин - паровозы, Сикорский - аэропланы, Попов - беспроволочный телеграф. Кроме того, мы страстно любим родину. И кроме того, поглядите у нас музыка и балет» [11, с. 649-650].

Резюмируя вышеизложенное, подчеркнем: обращение Куприна к творчеству Достоевского обусловлено, с одной стороны, общим для большинства русских писателей интересом к определенным человеческим типам («мечтатель»), мотивам («безумие»), жанровым схемам («рождественский рассказ»), с другой стороны - тем, что Достоевский как никто другой обеспечил тех, кто шел за ним, прецедентными именами и сюжетами, дающими возможность интерпретации событий новейшей истории, в том числе революции 1917 года.

Как показывает анализ публицистики А. И. Куприна, его апелляция к пророчествам Достоевского связана с тем, что «революция, по словам Н. А. Бердяева, совершилась по Достоевскому. Он раскрыл ее идейные основы, ее внутреннюю диалектику и дал ее образ. Он из глубины духа, из внутренних процессов постиг характер русской революции, а не из внешних событий окружающей его эмпирической действительности. "Бесы” - роман, написанный не о настоящем, а о грядущем» [3, с. 133-134].

\section{Литература}

1. А. И. Куприн о литературе. Минск, 1969. 455 с. Текст: непосредственный.

2. А. Куприн. Миниатюры. (Очерки и рассказы). Киев. 1897 // Русское богатство. 1898. Апрель. № 4, в отделе «Новые книги», бп. С. 25-28. Текст: непосредственный.

3. Бердяев Н. А. Миросозерцание Достоевского. Praha: YMCA-PRESS. 1923. 238 с. Текст: непосредственный.

4. Даренская Н. А. А. И. Куприн и Ф. М. Достоевский. О поэтике рассказа Куприна «Лунной ночью» // Филологический аспект. 2020. № 2(58). С. 49-52. Текст: непосредственный.

5. Достоевский Ф. М. Полное собрание сочинений: в 30 томах. Ленинград, 1972; 1988. Текст: непосредственный.

6. Жилякова Э. М. Мечтательство // Достоевский. Эстетика и поэтика. Словарьсправочник. Челябинск, 1997. 272 с. Текст: непосредственный.

7. Кайманова Т. А. Достоевский в творческом сознании Куприна // Купринская энциклопедия. Пенза, 2016. 852 с. Текст: непосредственный.

8. Кайманова Т. А., Ташлыков С. А. Лениниана Куприна // Купринская энциклопедия. Пенза, 2016. 852 с. Текст: непосредственный.

9. Кайманова Т. А., Ташлыков С. А. Очерк производственный // Купринская энциклопедия. Пенза, 2016. 852 с. Текст: непосредственный.

10. Кулешов Ф. И. Творческий путь А. И. Куприна. 1907-1938. Минск, 1986. 317 с. Текст: непосредственный.

11. Куприн А. И. Голос оттуда. 1919-1934 / составление, вступительная статья, примечания О. С. Фигурновой. Москва, 1999. 734 с. Текст: непосредственный.

12. Куприн А. И. Мы, русские беженцы в Финляндии. Публицистика (1919-1921). Санкт-Петербург, 2001. 431 с. Текст: непосредственный.

13. Куприн А. И. Пестрая книга. Несобранное и забытое / составление, вступление и примечания Т. А. Каймановой. Пенза, 2015. 628 с. Текст: непосредственный.

14. Куприн А. И. Пророчество второе // НРЖ. 1920. 2 марта. № 50. С. 2. Текст: непосредственный. 
15. Куприн А. И. Пророчество первое // НРЖ. 1920. 10 января. № 6. С. 2. Текст: непосредственный.

16. Куприн А. И. Собрание сочинений: в 9 томах. Москва, 1970-1973. Текст: непосредственный.

17. Куприн А. И. Хроника событий глазами белого офицера, писателя, журналиста / составление, вступительная статья, примечания О. С. Фигурновой. Москва, 2006. 672 с. Текст: непосредственный.

18. Медведева Д. А., Казаков А. А. Проблема безумия в романах Ф. М. Достоевского. 1865-1880-х гг. // Вестник Томского государственного университета. 2011. № 351 (октябрь). С. 33-38. Текст: непосредственный.

19. Саша Черный. Собрание сочинений: в 5 томах. Москва, 1996. Текст: непосредственный.

20. Трофимова Т. Б. Достоевский в публицистике А. И. Куприна 1919-1920-х гг. // Достоевский: материалы и исследования. 2010. № 19. С. 346-351. Текст: непосредственный.

21. Трунин С. Е. Рецепция Достоевского в русской прозе рубежа XX-XXI вв.: автореферат диссертации на соискание ученой степени кандидата филологических наук. Москва, 2008. 20 с. Текст: непосредственный.

22. У А. И. Куприна // Биржевые ведомости. 1915. 21 мая. (утр. вып.). № 14855. Текст: непосредственный.

Статья поступила в редакцию 19.11.2021; одобрена после рецензирования 29.11.2021; принята к публикации 10.12.2021.

\section{RECEPTION OF DOSTOEVSKY'S CREATIVITY IN THE WORKS BY ALEKSANDR KUPRIN}

Sergey A. Tashlykov

Cand. Sci. (Phil.), A/Prof.,

Irkutsk State University

1 Karla Marksa St., Irkutsk 664003, Russia

taschlykoff@mail.ru

Abstarct. The article analyzes the reception of Fyodor Dostoevsky's creativity in the fiction, social and political essays by Aleksandr Kuprin. The first part of the article focuses on such types of reception as communicative dialogue, interpretation, allusion. Communicative dialogue becomes apparent at the character level (the image of a dreamer) and the motive level (the motive of madness). We have revealed the similarities and differences of these images and motives in the prose by Dostoevsky and Kuprin. Another aspect of reception is interpretation of certain genre structures (Christmas story), as well as plots and images. Akeksandr Kuprin refers to the figurative system of Fyodor Dostoevsky's novels "The Brothers Karamazov" and "Demons", as well as to their ideological component. So, the second part of the article demonstrates that in the social and political essays of the emigrant period Kuprin acts as a commentator, partly as an integrator of the prophecies of someone who "feeled the ideological foundations and nature of the coming Russian revolution, and perhaps worldwide one" (N. A Berdyaev).

Keywords: Russian literature, Fyodor Dostoevsky, Aleksandr Kuprin, fiction, social and political essays, reception, types of reception, communicative dialogue, interpretation, allusion. 
ВЕСТНИК БУРЯТСКОГО ГОСУДАРСТВЕННОГО УНИВЕРСИТЕТА. ФИЛОЛОГИЯ

For citation

Tashlykov S. A. Reception of Dostoevsky's Creativity in the Works by Aleksandr Kuprin. Bulletin of Buryat State University. Philology. 2021; 4: 28-38 (In Russ.).

The article was submitted 19.11.2021; approved after reviewing 29.10.2021; accepted for publication 10.12.2021. 